\title{
Disinheritance of Daughters: Saving Tradition or Rejecting Modernity
}

\author{
Neena Rosey Kahlon ${ }^{1}$ and Ravi Inder Kaur ${ }^{2 *}$ \\ ${ }^{1}$ Assistant Professor, ${ }^{2}$ Senior Research Fellow \\ ${ }^{1 \& 2}$ Department of Sociology, Guru Nanak Dev University, Punjab, India \\ *Corresponding Author \\ E-Mail: kahlon22feb2009@ rediffmail.com, inderravi21@gmail.com
}

\begin{abstract}
Disinheritances of daughters from ancestral property is a well-established social fact as strong as the recognition of their legal right to inheritance; constitutionally and legally. Law, seen as potent tool for social change, attempt to provide equal and dignified claim to daughters Vis a Vis sons, but law does not operate in vacuum. The socio-cultural space regulates it functioning and nature and extent of delivery. However the explicit as well as implicit performance of Hindu Succession Act 1956 (as amended in 2005) within the Indian social space questions the underlining patriarchal structures of Indian society in particular and the larger goal of women emancipation in general. To this end, disinheritance of daughters at once disclose the intricately enmeshed issues of law, society and gender rights to fore front. The present paper is theoretical and attempts to conceptualize the larger issue of disinheritance of daughters within the contrast of tradition and modernity. The paper revolves around how socially noninvocation of inheritance rights confirms to traditional social structure while claiming these rights seems to be a modern phenomenon. The analysis revealed that the process of social change in India has been dominantly gendered and legally backed gender rights have few takers socially. Gendered Socialization, stigmas attached to independence of women and above all the overarching illusion of saving tradition and rejecting modernity emerges out to be the root causes for disinheritance of daughters from ancestral property.

Keywords: Inheritance, Socialization, Stigma and Patriarchal
\end{abstract}

\section{INTRODUCTION}

Inheritance, significantly is a social, cultural and legal institution through which property relations are build and maintained. In India, the issue of succession was defined along the contours of personal religious laws, regional customs as well as caste specific regulations. Along with this, there existed high diversity in terms of various schools governing inheritance and its doctrines across the length and breadth of the country. It is important to note that primarily women in India inherit any property in four capacities namely: a) as a daughter (unmarried or brother less married daughter) b) as a wife (from husband's property) c) as a widow (from husband's share in joint property and individual property) d) as a mother (from the son's property). To begin with, inheritance rights of women in above mentioned capacities had dominant bearing upon ancient and modern law givers equally. While the ancient law givers treated women as a consort of man, what all she was provided was partial self-dependence and subsistence. The modern law, on the other hand, committed to the ideals of equality, justice and inclusion wrestled with discriminatory statues of ancient law. Hence, the Hindu succession act brought into force on June 17, 1956 became the first gender-equitable law in India after century long British rule that excluded women from inheritance. The act amended and codified the law relating to instate succession among Hindus and brought about fundamental and radical changes in the law of succession, making provisions for married and unmarried daughters, sisters, widows and mothers to inherit land with full propriety rights to its disposal. (Vandana 2015:13)

Notably as a watershed development of invoking equal and dignified share to women in property, the law promised to be one of the most important mechanism of Women Empowerment and Gender Equality. However the explicit as well as implicit performance of Hindu Succession Act 1956 (as amended in 2005) rather paints a dismal picture. According to Oxfam India, about 17 Crore women work in agriculture and allied activities, producing about 60-80 percent of our food and 90 percent of dairy products but only 13 percent have property rights. The obvious reason for such a poor performance lies within the Indian social space whereby equal inheritance to daughters questions the underlining structures of Indian society. The social norms governing kinship and family still adore the self-sacrificing ideals of women hither to projection of socio-religious reform movements of 19th century which emerged as the counter-effect of colonial emancipation of women. Several customs like sati, female infanticide etc. were testimonial to British of the backward and helpless condition of Indian women, while the elite male reformers interpreted them as corrupt practices crept in to Hindu society owing to the external influence. Both traced back the antiquity of 'tradition', whereby male reformers invoked the myth of India's 'glorious past' thus, became nationalist revivalist and the British found their logic to secularize and enlighten Indian society and protect its women. Nationalist revivalism regarded the household and specifically conjugality, as "the last independent space left to the colonized Hindu" (Nair, 1996:50). Newly complied digests of Hindu and Muslim law of land, along with the class of loyal intelligentsia, the justice began to be delivered as per the English juridical interpretations. Although the British claimed that they only interpreted Hindu or Muslim law and did not interfere with it, in fact by setting up their law courts, the British altered the law-in some ways beyond recognition and irretrievably. 
The court judgments, overtime, became more authoritative than the Shastras from whom the supposedly derived their authority (Kishwar, 1994: 2149). Therefore the inheritance rights of women also came under the scanner of colonial government which attempted to alter the ancient economic position of Indian women through the lens of modernization. Since the early safeguard provided by the ancient law givers to women by way of stridhana, a necessary concomitance to male coparcener had been corroded due to judicial decisions, denial of equal rights to daughters only served to widen the gulf between gender divide. (Flavia 2014:82). Even in post-Independence India the property issues particularly the gendered division of property has centrally marked the conflict between the perpetuation of older systems of privilege and the establishment of modern new nation founded on the principles of individual rights and liberties. (Basu, 1999: 3) Thus a reworking of the Indian tradition on the lines of modernity was undertaken by the colonial government. Similar reform issues baffled the nascent government in post -independence era aligning with promise of equality and justice to women.

\section{METHODOLOGY}

In the above light, this paper attempts to situate an otherwise universal fact of disinheritance of daughters from ancestral property within the wide contrast between tradition and modernity. The paper revolves around how socially non-invocation of inheritance rights confirms to traditional social structure while legally claiming these rights seems to be a modern phenomenon. Is it the society trying to traditionalize the modern laws or are the laws aiming at modernizing the otherwise tradition bound society. The paper is a theoretical inquiry into certain aspects of Indian modernity vis-a -vis Indian tradition whereby the divide between these two, reasons for disinheriting daughters within the larger framework of gendered social change. The explanation and analysis reveals why the implementation of legal enablement's still remains a formidable challenge in Indian society.

\section{ANALYSIS AND DISCUSSION}

\section{A. Tradition and Modernity: A Contrast}

To begin with, there are some concepts in social sciences exists as such that they invoke fundamental contestation. No amount of dialectics can ever or may lead to define what they actually mean or include to the extent of excluding several other things. But as a starting point to effectively conceptualize the social reality and moreover to situate the disinheritance of daughters within the larger paradigm of law, society and gender rights, the terms Tradition and Modernity renders a formidable explanation. No doubt, in academics there exists; varied, elaborate and often complex definitions of Modernity and Tradition, nevertheless these, to an extent, manifest themselves tangibly. Modernity and Tradition, in a literal senses till depend on appearance.
Modernity may entail western clothing, branded wear, well equipped houses, automobiles etc. while at the same time tradition may invoke rustic rural setting devoid of technological innovations. Modernity and tradition, in terms of mental outlook is often brushed aside. Some amount of modern outlook is warranted from a person dressed in western clothing. Though it may not be the case. So therefore emerges the obvious puzzle as to what constitute Modernity and Tradition, as well as their essential elements. Do they always occur in contrast or there exists a continuum? Along with this a convenient question may also arise, what consequences do entail being following modernity or tradition and at what cost? Are we creating something new out of old when we use the term modern or we are still referring to tradition reconstructed and reaffirmed in the wake of modernity.

\section{B. Aspects of Contrast}

Given such a perplexity, tackling Modernity and Tradition in contrasting terms at first seems apt. In this case, tradition would mean something hierarchical, fixed and unequal while modernity promises equality, mobility and fairness. Modernity in this way becomes the project of emancipation and empowerment through which differences would be equalized, injustices reversed and dignity prevailed. In contrasting terms, following aspects emerge.

Firstly, concepts of modernity and tradition appear relative to time and space. What may be modern or say culturally shocking may be well received and practiced in other society says west. Disinheritance of daughters in this sense seems sticking to traditional patriarchal structure of Indian society where authority over resources vests with men. While inheritance to men simply seems logical because it has always been followed this way, i.e. the precedence of tradition. Equality of sexes is not the maxim of Indian society and patriarchy rules the roost. It was felt that with the abolition of coparcenary and inheritance to daughters, as intended by the amendment to Hindu Succession Act of 1956 in 2005. Since the passing of Act, patriarchal forces has devised several ways to maintain their assertive control over income generating resources thereby denying women the benefits of legal enablement. Taking the recourse of fallout of Act, potential female inheritors are towed to write off their claims in favor of brothers. Popularly likhatpadhat (formalization of rights) is made to be signed by girls on the pretext of their own sweet will. Post-1956, there was a surge in gift and sale deeds registered in favor of male members in Punjab and Haryana. (Vandana 2015:13). As expected Hindu society received a moral setback through the act. In fact, due to severe opposition coparcenary system had to be maintained which resulted in the denial of rights to women in the ancestral home and property? (Flavia 2014:78)

Secondly, to define as to what constitute modern and tradition, the onus in present times has shifted from community to 'State' via 'Law'. Customs forms the substantial part of tradition along with folkways and mores. 
Law in present times works as potent tool of social change by filtering and modernizing the earlier practiced customs. India has a long and complex colonially mediated legal history along with socio-religious reform movements that constructed and reformed tradition from modernity itself. The invocation of images of Sita, values of sacrifice and true womanhood prevented the modernity to reach Indian women. According to Uma Chakravarti, "In nineteenth century, the education itself was gendered and so was the reform". This mediated modernity corresponded the term change with modernity and the obvious guard was reinvention of tradition". Hence laws and acts were creating and reinforcing traditions legally. The famous abolition of sati on the part of Raja Ram Mohan Roy hailed as father of Indian Renaissance was advanced on the premise that it was invalidated by shastras, i.e. not backed by tradition. Similarly, disinheritance of daughters seems valid in the presence of a customarily practiced long standing tradition of dowry which rarely include piece of agricultural land.

Thirdly, convoluted modernity and tradition fiasco separated the earlier overlapping categories of law, morality and religion. Flavia Agnes says that earlier law, morality and religion were termed as dharma. Thus the colonial project of "knowing Indian natives" for administrative convenience lead to absurd quest for authentic Indian tradition by unearthing indigenously existing systems of jurisprudence, marriage and family etc. A complete digest of Hindu and Muslim laws from British lens thus emerged and Indians got provided with English law as the law of India. Consequently came several legislations on women property rights, with widows getting a share in husband's property through historic hailed women's right to property act, 1937. Ironically this so-called modern act gave separate estate to women with limited rights therefore whitewashing the very purpose for which came into force.

Fourthly, uniformity is another aspect of modernity while tradition entailed plurality of legal and customary codes. Sabberwal discusses how tradition rejects uniformity in case of India. These days with the issue of talaq being on the forefront, we are still nibbling at the idea of Uniform Civil Code (UCC). UCC has been in incubation since early years of independent India. The strive for uniform and single civil code got strengthened with the constitutional mandate of equality and justice. To this extent, laws relating to marriage, divorce and inheritance attracted legal correction. But the dominant contrast of modernity and tradition and the caution of not disturbing the traditional set up lead to the phasing out of UCC. Resignation of Ambedkar over the issue and triumph of feudal patriarchal forces in Indian polity reflected the stronghold of tradition. Hindu succession act, 1956 introduced daughter as simultaneous heir along with son and widow by retaining the Mitaksharacoparcenery (body of those holding stake in joint family property which included only male lineage) of which daughters were not the part. But the provisions were cautiously framed so as it hardly delivers in the sociocultural hostile arena of Indian politics. This legal entitlement left sufficient scope for men to disinherit daughters even in the absence of male heirs. Kothari opines how the dichotomous relationship between tradition and modernity lead to a 'cognitive hiatus' of entrenched inequality in HSA that it took more than half a century to correct a historical wrong. It is only in 2005 amendment to the act that daughters were included in the coparcenery. The amendment gave same rights and capacities to both son and daughter but what remains the cause of concern is its implementation. Even after the amendment there are still many legal discrepancies which work unfavorably to women thereby showing how law intends not to meddle with tradition. In addition to this, the tradition of dowry and consequential violence every now and then put a large number of daughters at the receiving end. The phenomenon of dowry explains why legal enablements fail to deliver on socially hostile grounds. Thus Indian women find themselves in sandwiched or double bind between a legal wrong and a cultural right in case of dowry and legal right and a cultural wrong in case of inheritance.

Fifthly, modernity takes the scope of political and legal action beyond the public into private sphere which was earlier the bastion of religion and tradition. Here is worked the popular slogan "personal is political". In words of Bal, challenging the traditional views on family and personal life as outside the domain of politics, they assigned that private sphere was in fact primary zone of power relations and of gendered inequality. Central to this public/private dichotomy is definition of men as rational, objective and powerful, adjectives adorned by tradition while women lack agency of reason and power which modernity promises to deliver.

It is within this paradigm of contrast between modernity and tradition, that Indian state is modernizing Indian tradition. Tradition is well guarded while modernity performs an ornamental service in the periphery of Indian political discourse. In the words of Avijit Pathak, in India modernity is not denied, yet seen as something alien that might destroy cultural identity and even when modernity was celebrated the sanctity of our core culture was not forgotten. Even after the amendment of 2005, Hindu women only theoretically acquired equal rights to the "ancestral property" of parents in cases of intestate succession but they could be still disinherited through wills. (Basu, 1999: 3). Moreover, under the act the property of the childless women devolves upon the husbands heirs and only in their absence would it devolve upon the women's own parents. A further and incomprehensible distinction was made between the heirs of father and those of the mother of a female who are placed in an inferior category (Section.15 (1) (d) and (e) of Hindu Succession Act, 1956). This provision, in reality weakens the position of female heirs, where the general mode of inheritance is patrilineal and patriarchy holds inexplicable strength. Thus the role of law as generator and guarantors of rights seems obvious in such a situation. Law has to be equal and just. Nevertheless as the analysis of Hindu Succession Act in this paper highlight the biased undertones 
of otherwise optimistic and progressive legal document. In fact, legal strategies have indeed a role to play in removing entrenched inequalities in society which exclude or preclude women's equal access to resources. (Patel, 2006: 1256). Therefore amending the law and creating non biased legal frameworks is the starting point for redressing gender discrimination. However Basu contends that over reliance on law for bringing about change is fundamentally problematic and those laws are most effective when they legitimize changes that are socially amenable. To that extent changes in legal structures ought to emanate from social space for greater acceptance and efficiency.

To this end, India, at societal and cultural plane, exhibits irreconcilable schism of Modernity and tradition. Sociologically, it has been firmly established that women rights in inheritance contradicts with their traditional roles. In this regard women's issue of inheritance is intricately linked to Hindu notion of family, various cultural norms, values and institutions. Bina Aggarwal opines that it is strictly expected of women not to assert their economic rights in India. This brings out the need to extend the analysis of the law to relations and organizations and to locate it beyond the public spheres and in the household. (Patel, 2006:1262). Usually the question of inheritance by women is defined as unethical and immoral as good women do not inherit property. Colored by the patriarchal social norms and ethos, women themselves usually evade the issue and sign off their shares to their brothers. This lack of the social sanction of daughters being viable heirs to the inherited property accounts much for the gender inequality in India. Daughters are married off on lines of village exogamy and with handsome amount of dowry; which further reinforces their disinherited status. Notably the lack of social legitimacy for inheritance of daughters, their social insecurity of losing the kinship ties, and the problem of social stigmatization are the key reasons attributing to disadvantageous economic position of daughters.

\section{CONCLUSION}

The question of women inheritance becomes crucial in present times owing to the inevitable relationship between economic equality and social equality and to the more pertinent issue of women empowerment. Though, legally daughters can inherit the ancestral property likewise sons of the family but disappointment looms large while assessing in what measure daughters have accessed this right and subsequent repercussions. Nevertheless, while the law intended to empower women though conditionally, the perspective of contrast between tradition and modernity renders this emancipation problematic. Ideologically and practically both tradition and modernity are seen as oppositional categories that can't co-exist and if all they do, there should be a limit to the trajectory of change. Indian women have to confront this struggle between modernity and tradition on daily basis, where clear cut gender roles and boundaries limit their capacities. It is revealed that the process of social change in India has been dominantly gendered and legally backed gender rights have few takers socially. Gendered Socialization, stigmas attached to independence of women and above all the overarching illusion of saving tradition and rejecting modernity emerges out to be the root causes for disinheritance of daughters from ancestral property.

\section{REFERENCES}

[1] Agarwal, Bina. (2005). A Field of One's Own: Gender and Land Rights in South Asia, in Dowry and inheritance. ed. Srimati Basu, 91-110. New Delhi: Women Unlimited.

[2] Agnes \& Flavia. (2015, November 21). Women \& the uniform civil code. Deccan Chronicle.

[3] Agnes \& Flavia (2014). Law and Gender Inequality. New Delhi: Oxford University Press.

[4] Bal \& Gurpreet. (2016). Identity, Status and Empowerment: Contemporary Gender Issues. New Delhi: Rawat publications.

[5] Basu \& Srimati. (1999). She Comes to Take Her Rights: Indian Women, Property and Propriety. New York: State University Press.

[6] Chakravarti \& Uma. (2011). Bringing Gender into History: Women, Property and Reproduction, Economic Political and Weekly, 46(33), 39-41.

[7] Kishwar \& Madhu. (1994). Codified Hindu law; Myth and Reality, Economic Political and Weekly, 29(33), 2145-2161.

[8] Kothari \& Rajni. (2012). Politics in India. New Delhi: Orient Black swan.

[9] Nair \& Janaki. (1996). Women and Law in Colonial India: A Social History. New Delhi: Kali for Women.

[10] Patel \& Reena. (2006). Hindu Women's Property Rights in India: A Critical Appraisal. Third World Quarterly, 27(7), 1255-1268.

[11] Pathak \& Avijit. (1998). Indian Modernity: Contradictions, Paradoxes, Possibilities. New Delhi: Gyan Publishing House.

[12] Shukla \& Vanadana. (2015, September 12). Hindu Women and Property: Myth vs. Reality. The Tribune. 